\title{
Characteristics of Surface Ozone in Five Provincial Capital Cities of China during 2014-2015
}

\author{
Xin Wang ${ }^{1,2}$, Zhenxing Shen ${ }^{1,3, *} \mathbb{0}$, Zhuoyue Tang ${ }^{1}$, Guohui Li ${ }^{3}$, Yali Lei ${ }^{1}$, Qian Zhang ${ }^{1}$, \\ Yaling Zeng ${ }^{1}$, Hongmei $\mathrm{Xu}^{1}{ }^{1}$, Junji Cao ${ }^{3}$ and Renjian Zhang ${ }^{4, * \mathbb{i}}$ \\ 1 Department of Environmental Sciences and Engineering, Xi'an Jiaotong University, Xi'an 710049, China; \\ lanlantuxinxin@gmail.com (X.W.); tangzycoral@stu.xjtu.edu.cn (Z.T.); 18682901770@163.com (Y.L.); \\ zhangqian2011@stu.xjtu.edu.cn (Q.Z.); zengyaling@hotmail.com (Y.Z.); xuhongmei@mail.xjtu.edu.cn (H.X.) \\ 2 Multiphase Chemistry Department, Max Planck Institute for Chemistry, 55128 Mainz, Germany \\ 3 Key Lab of Aerosol Chemistry \& Physics, Institute of Earth Environment, Chinese Academy of Sciences, \\ Xi'an 710049, China; ligh@ieecas.cn (G.L.); cao@loess.llqg.ac.cn (J.C.) \\ 4 Key Laboratory of Regional Climate-Environment Research for Temperate East Asia, Institute of \\ Atmospheric Physics, Chinese Academy of Sciences, Beijing 100029, China \\ * Correspondence: zxshen@mail.xjtu.edu.cn (Z.S.); zrj@mail.iap.ac.cn (R.Z.)
}

Received: 28 November 2019; Accepted: 10 January 2020; Published: 16 January 2020

\begin{abstract}
Ozone $\left(\mathrm{O}_{3}\right)$ pollution has become an increasing concern in China since elevated surface $\mathrm{O}_{3}$ concentrations were observed in recent years. In this study, five provincial cities (Beijing, Shanghai, Guangzhou, Xi'an, and Hefei) located in different regions of China were selected to study the spatiotemporal variations and affecting factors of $\mathrm{O}_{3}$ concentrations during 2014-2015. Beijing, Shanghai, and Guangzhou had suffered more severe $\mathrm{O}_{3}$ pollution, yet Beijing had the highest number of days that exceeded the Chinese MDA8 (maximum daily $8 \mathrm{~h}$ average) standard of $160 \mu \mathrm{g} \mathrm{m}^{-3}$. MDA8 $\mathrm{O}_{3}$ exhibited different seasonal patterns among the five cities. In Beijing and Xi'an, MDA8 $\mathrm{O}_{3}$ showed the highest in summer and lowest in winter. Guangzhou also had the highest $\mathrm{O}_{3}$ concentration in summer, but had similar levels in other three seasons. The $\mathrm{O}_{3}$ levels were similarly high in Shanghai during spring, summer, and autumn, while in Hefei, $\mathrm{O}_{3}$ concentration peaked in autumn. No significant difference between weekend and weekday $\mathrm{O}_{3}$ levels was observed in all the five cities. The diurnal cycle reached a maximum in the afternoon and a minimum in the early morning, which was consistent in the five cities. Correlation analyses showed that the associations between $\mathrm{O}_{3}$ and the other five criteria air pollutants, as well as meteorological parameters, were substantially different among the five cities. Air mass cluster analyses during episodic days revealed that the short-distance transport of $\mathrm{O}_{3}$ and its precursors had a greater impact for high $\mathrm{O}_{3}$ pollution in the five cities. Overall, our results demonstrate that $\mathrm{O}_{3}$ pollution exhibited great divergence among different regions and thus region-oriented control measures are suggested to reduce $\mathrm{O}_{3}$ pollution in China.
\end{abstract}

Keywords: surface ozone; meteorological parameter; air pollution; China

\section{Introduction}

Tropospheric ozone $\left(\mathrm{O}_{3}\right)$ plays important roles in air quality, climate change, and ecosystem health $[1,2] . \mathrm{O}_{3}$ is a critical photochemical oxidant in the troposphere and affects atmospheric chemistry and air quality [3]. It is also one of several important greenhouse gases contributing to climate change due to its absorption of the Earth's infrared radiation at $9.6 \mu \mathrm{m}$ [4]. Moreover, excessive ozone is recognized to be a threat to human health and vegetation [5]. There is evidence that surface $\mathrm{O}_{3}$ can cause cardiovascular and respiratory dysfunction and contribute to increased levels of mortality [6-8]. 
Ozone near the surface is a secondary air pollutant, mainly generated by photochemical reactions involving nitrogen oxides $\left(\mathrm{NO}_{\mathrm{x}}=\mathrm{NO}+\mathrm{NO}_{2}\right)$, carbon monoxide $(\mathrm{CO})$ and volatile organic compounds (VOCs) in the presence of sunlight. Due to the increase of anthropogenic emissions of $\mathrm{O}_{3}$ precursors, a steady rise of $\mathrm{O}_{3}$ level has been observed around the world since the 1950s [9]. The increasing trend has been extensively alleviated in Europe and the United States owing to stringent emission control measures since the 1990s $[10,11]$. However, the $\mathrm{O}_{3}$ level in Asia, especially in China, is still increasing due to rapid urbanization and industrialization [12].

However, China has suffered from severe fine particulate matter $\left(\mathrm{PM}_{2.5}\right)$ pollution in winter. Research and control have prioritized $\mathrm{PM}_{2.5}$ over the past few years. In contrast, less is known about ozone pollution, partly due to a lack of monitoring of atmospheric ozone and its precursors. Extensive ozone monitoring has begun to be established in urban and rural locations by national and local environmental and meteorological agencies since 2012 [12]. With the establishment of a national air quality monitoring network, large-scale real-time $\mathrm{O}_{3}$ monitoring data became available [13]. A few studies therefore have investigated the spatial and temporal distribution of surface $\mathrm{O}_{3}$ on a nationwide scale or city scale [13-16]. In particular, it was found that particulate pollution has been alleviated due to strict emission control policies, while nationwide $\mathrm{O}_{3}$ levels were increasing during 2013-2017 [17,18].

In order to further evaluate the characteristics of $\mathrm{O}_{3}$ pollution in major cities of China after the implementation of the "Air Pollution Prevention and Control Action Plan" from 2013 [19], we selected the period 2014-2015, i.e., two years' dataset immediately after the plan and five provincial cities to discuss in detail in this study. The period of 2014-2015 was selected in order to investigate the characteristics of $\mathrm{O}_{3}$ pollution and the relationships between $\mathrm{O}_{3}$ and the other criteria air pollutants and meteorological conditions after the decrease of other criteria air pollutants [18]. The cities selected in this work were encountering severe air pollution and are located on the regions that air pollution control policies are being focused. Additionally, these cities are located in different regions of China (see Figure 1) and have different geographies, climates, as well as economic development levels. The spatiotemporal variations and weekly and diurnal cycles of $\mathrm{O}_{3}$ in the five cities were analyzed, and the associations between $\mathrm{O}_{3}$ and its affecting factors (e.g., precursors and meteorological factors) were discussed.

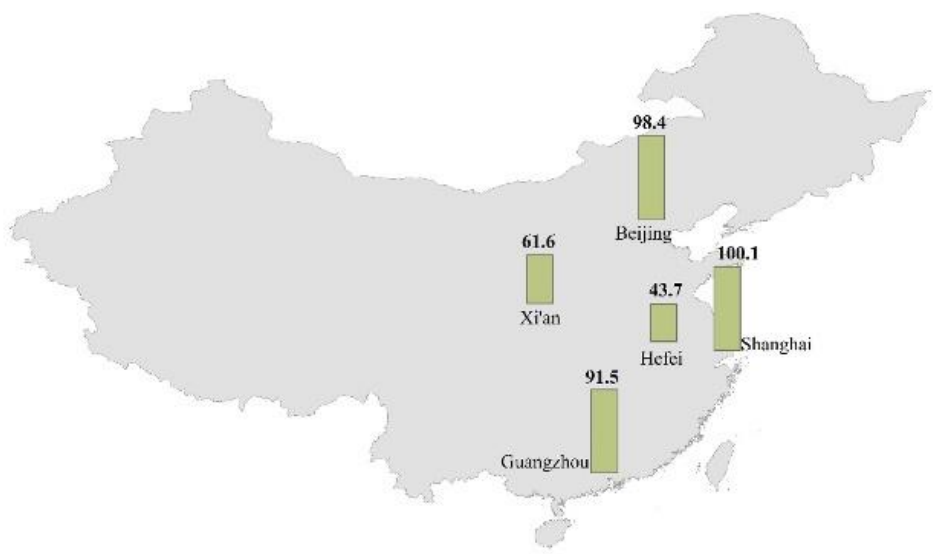

Figure 1. Map showing the locations of five studied cities and two-year averaged MDA8 ozone concentrations $\left(\mu \mathrm{g} \mathrm{m}^{-3}\right)$ during 2014-2015.

\section{Methods and Data}

\subsection{Study Cities}

The field experiments were conducted in five provincial capital cities of China located in different regions (see Figure 1), i.e., Beijing (BJ, Northern), Shanghai (SH, Eastern), Guangzhou (GZ, Southern), Xi'an (XA, Northwestern), and Hefei (HF, Southeastern). 
Beijing is the capital of China, situated at the Northwestern periphery of the densely populated North China Plain. The climate characteristics of Beijing is hot, humid in summer due to the East Asian monsoon, and cold, windy and dry in winter, which reflects the influence of the vast Siberian anticyclone [20]. Beijing is an important transportation hub with five ring roads, nine expressways, eleven national highways, and ten conventional railways linking to all parts of China [14].

Shanghai is located in the Yangtze River Delta (YRD) and is bounded to the East by the East China Sea. It is the largest city in China by population with a population over 24 million in 2014 (http://www.stats.gov.cn/tjsj/ndsj/2015/indexeh.htm). It also has China's largest petrochemical complex, steel manufacturer, seaport, and over 2 million vehicles [21]. Shanghai has a humid subtropical climate with cold and damp winter and hot and humid summer, susceptible to thunderstorms and typhoons [14].

Guangzhou is a representative megacity in the Pearl River Delta (PRD) region in Southern China. It is a major trading port, which has been a "world factory" for a wide range of consumer products [21]. Guangzhou has a humid subtropical marine climate influenced by the East Asian monsoon, spanning from April through September [22].

Xi'an, the capital city of Shaanxi province in Northwestern China, is located in the Guanzhong Plain area with a topographic basin surrounded by the Qinling Mountains to the South and the Loess Plateau to the North $[23,24]$. This region is currently encountering severe air pollution due to rapid increase of motor vehicles and the growth in energy consumption. $\mathrm{Xi}^{\prime}$ an has a temperate climate as it is situated on the borderline between a semi-arid climate and humid subtropical climate (http://rgd29.org/miscellaneous/about-xian).

Hefei, the capital city of Anhui province and the sub-center of YRD region, is planning to be focused on the next development in China. Similar to Shanghai, Hefei, as an inland city, also features a humid subtropical climate with cold and damp winters, and hot and humid summers.

\subsection{Data Collection}

Hourly monitoring data of $\mathrm{O}_{3}$, as well as other five criteria pollutants, i.e., $\mathrm{CO}, \mathrm{SO}_{2}, \mathrm{NO}_{2}, \mathrm{PM}_{2.5}$, and $\mathrm{PM}_{10}$ in five studied cities, were obtained from China National Environmental Monitoring Centre for the period from January 2014 to December 2015. All the measurements were conducted at the national air quality monitoring sites located in each city. There were 19, 9, 10, 13, and 10 air quality monitor sites in BJ, SH, GZ, XA, and HF, respectively. The air pollutants concentrations reported in this study were calculated by averaging the concentrations at all sites in each city. Note that a sanity check was conducted on the hourly data at individual sites to remove problematic data points before calculating the average concentrations. The detailed data monitoring techniques have been described in previous studies [25]. Briefly, automated monitoring systems were installed and used to measure the ambient concentrations of $\mathrm{SO}_{2}, \mathrm{NO}_{2}, \mathrm{O}_{3}$, and $\mathrm{CO}$ according to China Environmental Protection Standards HJ 193-2013 (http://www.es.org.cn/download/2013/7-12/2627-1.pdf), and of $\mathrm{PM}_{2.5}$ and $\mathrm{PM}_{10}$ according to China Environmental Protection Standards HJ 655-2013 (http://www.es.org.cn/download/ 2013/7-12/2626-1.pdf). Maximum daily 8-h average (MDA8) is a widely used daily ozone metric for air quality regulation and human health impact studies in many regions including China [17]. Therefore, we calculated an MDA8 for $\mathrm{O}_{3}$ concentration in this study. MDA8 $\mathrm{O}_{3}$ concentrations were calculated when there were valid data for at least $5 \mathrm{~h}$ for every $8 \mathrm{~h}$ [13].

Additionally, hourly meteorological parameters including ambient temperature, relative humidity (RH) and wind speed between January 2014 and December 2015 were obtained from Weather Underground (https://www.wunderground.com/). Note that the meteorological data from Weather Underground is monitored at the airports of each city. The meteorological data at the airports may not be fully representative for the citywide average data. 


\subsection{Back Trajectory Analysis}

Air mass back-trajectory was calculated using TrajStat to trace the sources and transport pathways of $\mathrm{O}_{3}$ or its precursors. TrajStat is a free software with various trajectory statistical functions [26]. It can do PSCF (Potential Source Contribution Function) and CWT (Concentration Weighted Trajectory) analyses to identify pollution sources from long-term air pollution measurement data. Back trajectory analysis was performed at $1000 \mathrm{~m}$ height for selected ozone episodic days, and two-day ( $48 \mathrm{~h}$ ) back trajectories were used to perform the cluster analysis.

\section{Results and Discussion}

\subsection{Overview of $M D A 8 \mathrm{O}_{3}$ Levels}

The average concentrations of surface $\mathrm{MDA}_{8} \mathrm{O}_{3}$ during 2014-2015 were 98.4, 100.1, 91.5, 61.6, and $43.7 \mu \mathrm{g} \mathrm{m}^{-3}$ in BJ, SH, GZ, XA, and HF, respectively (Figure 1 and ). BJ, SH, and GZ are the top three megacities in China with dense populations and well-developed economies. The averaged MDA8 $\mathrm{O}_{3}$ levels were similar in these three cities and much higher than that in XA and HF. This result may indicate a high contribution of anthropogenic activities on $\mathrm{O}_{3}$ pollution in Chinese major cities. For example, it was suggested that higher vehicle numbers $[27,28]$ and serious traffic congestion in $\mathrm{BJ}, \mathrm{SH}$ and GZ, resulting in higher emissions of $\mathrm{NO}_{x}$ and VOCs, which is suggested to be a major cause of $\mathrm{O}_{3}$ formation in these cities [21]. Furthermore, BJ $\left(311.9 \mu \mathrm{g} \mathrm{m}^{-3}\right), \mathrm{SH}\left(272.8 \mu \mathrm{g} \mathrm{m}^{-3}\right)$, and GZ $\left(285.6 \mu \mathrm{g} \mathrm{m}^{-3}\right)$ had higher values for maximum MDA8 $\mathrm{O}_{3}$ than XA $\left(205.4 \mu \mathrm{g} \mathrm{m}^{-3}\right)$ and $\mathrm{HF}\left(235.6 \mu \mathrm{g} \mathrm{m}^{-3}\right)$ (Table 1). However, it should be noted that all these maximum values exceeded the Chinese Grade II national air

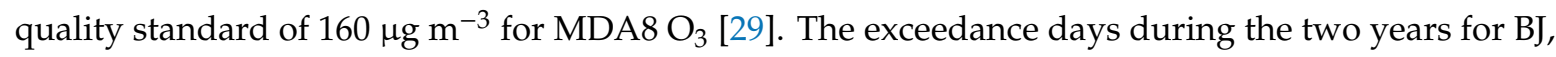
$\mathrm{SH}, \mathrm{GZ}, \mathrm{XA}$, and HF were 118, 52, 64, 20, and 28, respectively.

Table 1. The MDA8 $\mathrm{O}_{3}$ concentrations in five provincial capital cities during 2014-2015.

\begin{tabular}{cccccc}
\hline \multirow{2}{*}{ City } & \multicolumn{2}{c}{$\mathbf{O}_{\mathbf{3}}\left(\mu \mathrm{g} \cdot \mathrm{m}^{-3}\right)$} & \multicolumn{2}{c}{$\begin{array}{c}\text { Exceedance } \\
\text { (days) }\end{array}$} \\
\cline { 2 - 5 } $\mathbf{2}^{\mathbf{3}}$ & Mean & S.D. ${ }^{\mathbf{1}}$ & Min & Max & 116 \\
Beijing & 98.4 & 64.0 & 1.0 & 311.9 & 52 \\
Shanghai & 100.1 & 43.0 & 14.4 & 272.8 & 64 \\
Guangzhou & 91.5 & 49.7 & 2.0 & 285.6 & 20 \\
Xi'an & 61.6 & 44.2 & 3.0 & 205.4 & 28 \\
Hefei & 43.7 & 44.0 & 5.0 & 235.6 & 28 \\
\hline
\end{tabular}

${ }^{1}$ : standard deviation. ${ }^{2}$ : Number of days with $\mathrm{MDA} 8 \mathrm{O}_{3}$ exceeding the Chinese Grade II national air quality standard $\left(160 \mu \mathrm{g} \cdot \mathrm{m}^{-3}\right)$ during 2014-2015.

\subsection{Seasonal and Monthly Variation}

Figure 2 shows the seasonal and monthly variations of $\mathrm{MDA}_{8} \mathrm{O}_{3}$ concentrations in the five cities. The averaged surface $\mathrm{O}_{3}$ concentrations were higher in warm seasons, but the temporal patterns were different in these cities. Seasonal MDA8 $\mathrm{O}_{3}$ concentrations in BJ peaked in summer (June to August), followed by spring (March to May), autumn (September to November), and were lowest in winter (December to February). A similar trend was found in XA. However, in XA, a distinctly high MDA8 $\mathrm{O}_{3}$ concentration was in summer (Figure 2a), corresponding to that in July and August (Figure 2b). Meanwhile, the MDA8 $\mathrm{O}_{3}$ concentrations in BJ showed similar levels from April to August, resulting in a smaller difference between spring and summer. It is worth noting that the averaged $M D A 8 \mathrm{O}_{3}$ concentrations in BJ during May to August were in the range of $151-161 \mu \mathrm{g} \mathrm{m}^{-3}$, which were close to or even a bit higher than the Chinese Grade II national air quality standard of $160 \mu \mathrm{g} \mathrm{m}^{-3}$ [29]. The MDA8 $\mathrm{O}_{3}$ concentrations in $\mathrm{SH}$ were comparable in spring, summer, and autumn, but summer had wider concentration ranges. The minimum MDA8 $\mathrm{O}_{3}$ was in winter. In GZ, the $\mathrm{MDA}_{8} \mathrm{O}_{3}$ also peaked in summer with a broad range, and the $\mathrm{MDA}_{8} \mathrm{O}_{3}$ peak value was comparable with other three seasons. Multiple peaks were found in the monthly distribution of $\mathrm{MDA}_{8} \mathrm{O}_{3}$ in GZ. Some peaks were 
not within May to October as the patterns in the other four cities, e.g., a peak occurred in January. In $\mathrm{HF}$, unlike the other four cities, seasonal $\mathrm{MDA}_{8} \mathrm{O}_{3}$ concentrations peaked in autumn. The other three seasons showed similar averaged $\mathrm{MDA} 8 \mathrm{O}_{3}$ concentrations. Correspondingly, the peak value of monthly MDA8 $\mathrm{O}_{3}$ concentrations reached in September, followed by August and October, and other months, showed comparably low $\mathrm{MDA}_{8} \mathrm{O}_{3}$ concentrations.

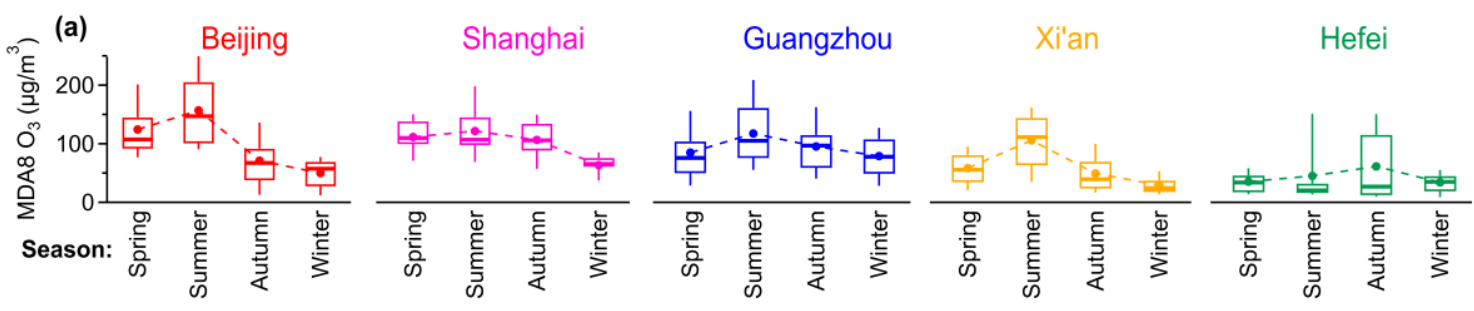
(b)

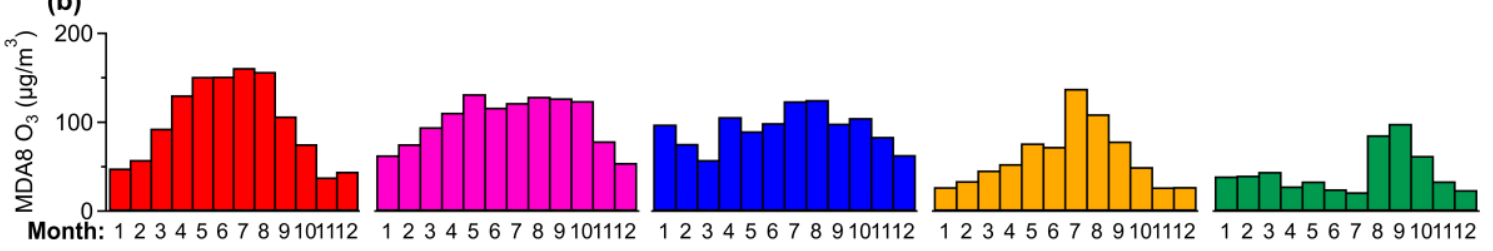

Figure 2. Seasonal (a) and monthly (b) variations of MDA8 $\mathrm{O}_{3}$ concentrations in the five cities. The boxes represent the 25 th percentile (lower edge), median (solid line), mean (dot with dashed line), and 75th percentile (upper edge). The whiskers above and below the box indicate the 90th percentile and 10th percentile.

The seasonal patterns of $\mathrm{O}_{3}$ found in this study were also compared to the results from previous studies. We found the seasonal patterns in $\mathrm{BJ}$, $\mathrm{SH}$ were consistent with the data collected during 2013 [14], and data collected during 2014-2016 as well [16]. The seasonal pattern of $\mathrm{O}_{3}$ in $\mathrm{XA}$ is also consistent with previous reported data collected in 2008 [30]. Interestingly, we found the reported seasonal pattern of $\mathrm{O}_{3}$ in GZ peaked in autumn for data collected during 2013 [14] or prior to that [31]. However, recent studies have reported a maximum $\mathrm{O}_{3}$ concentration in summer in GZ for data collected after 2013 [13,16], which is consistent with our study. Further studies are warranted to understand which are the underlying mechanisms or if strict emission control measures after 2013 resulted in the change of seasonal patterns in GZ. Finally, to our knowledge, the seasonal patterns of $\mathrm{O}_{3}$ in $\mathrm{HF}$ has not been reported previously.

\subsection{Weekly and Diurnal Patterns}

Figure 3 shows the weekly cycles of MDA8 $\mathrm{O}_{3}$ concentration anomalies in the five cities. No consistent trend of a weekly pattern was found among cities. Previous studies have proposed that $\mathrm{O}_{3}$ might display obvious weekend effects, i.e., the occurrence of higher $\mathrm{O}_{3}$ concentrations on the weekend, especially in large cities [32-36]. The weekend effect could be due to a higher VOC/NO ratio at weekends as a result of a smaller decrease in VOCs and much lower $\mathrm{NO}_{\mathrm{x}}$ concentrations on the weekend [33]. However, the one-way analysis of variance (ANOVA) tests show that $\mathrm{O}_{3}$ concentrations between weekends and weekdays were not significantly different $(p>0.05)$ in the five cities during 2014-2015. Here, we define Saturday, Sunday, and Monday as weekends, Wednesday, Thursday, and Friday as weekdays, which was suggested in a previous study [33]. The definition of Monday as part of the weekend is based on the finding that both the concentrations of $\mathrm{O}_{3}$ and its precursors on Monday are still highly affected by the reduced human emissions and lower accumulation on Saturday and Sunday [33]. Additionally, the $\mathrm{NO}_{2}$ and $\mathrm{CO}$ (as a proxy of VOCs) concentrations did not display a significantly weekend effect ( $p>0.05$, ANOVA test) except $\mathrm{CO}(p=0.04)$ in XA. Our results are different with previous studies showing $\mathrm{O}_{3}$ weekend effects in BJ [33], $\mathrm{SH}$ [34], and Nanjing (the provincial city of Jiangsu province, China) [32]. The different findings could be due to different study periods. Since 
our study period is the most recent one compared to the other three studies, it may indicate that the vehicle restrictions and other mitigation strategies of air pollution in Chinese large cities have been affecting the weekly pattern of $\mathrm{O}_{3}$. For example, Tong, et al. [37] also showed the difference of $\mathrm{O}_{3}$ levels between weekdays and weekends was insignificant $(p>0.05)$ in Ningbo (a sub-provincial city near Shanghai) during 2012-2015. However, it should be noted that the data in this study is the citywide average concentrations calculated by averaging the concentrations at all sites in each city, while the other three studies investigated specific sites in the cities. Hence, the insignificant difference of $\mathrm{O}_{3}$ concentrations between weekends and weekdays could also be partially due to the citywide average concentration used in this study, since the $\mathrm{O}_{3}$ concentrations and patterns may differ largely among the urban, suburban, and rural sites.

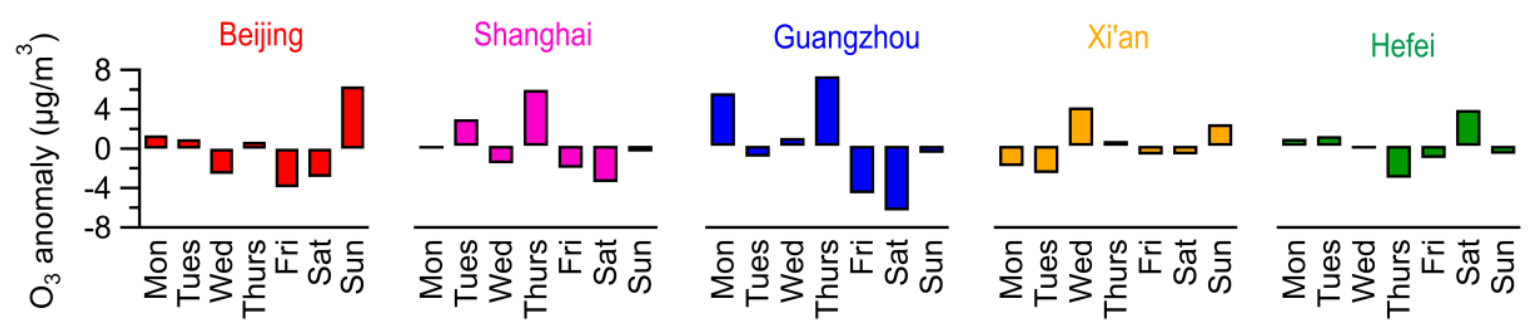

Figure 3. The weekly cycle of $\mathrm{MDA}_{8} \mathrm{O}_{3}$ concentration anomalies in the five cities.

The diurnal variations of hourly $\mathrm{O}_{3}$ concentrations in the five cities are displayed in Figure 4. Similar patterns were observed among the five cities. The diurnal curves show that $\mathrm{O}_{3}$ had a minimum in the morning around 8:00 and started to increase rapidly, reached the maximum at around 15:00, and then decreased in the evening. The diurnal cycles observed in this study agreed with many other studies that have illustrated that these diurnal variations were controlled both by local photochemical production and changes in boundary layer mixing $[1,12,15,16]$. Interestingly, a small peak occurred at 2:00 for $\mathrm{SH}$, which was not found in the other four cities. The maximum values were much higher in GZ $\left(115.7 \mu \mathrm{g} \mathrm{m}^{-3}\right)$, SH $\left(108.5 \mu \mathrm{g} \mathrm{m}^{-3}\right)$, BJ $\left(107.9 \mu \mathrm{g} \mathrm{m}^{-3}\right)$ than that in XA $\left(67.2 \mu \mathrm{g} \mathrm{m}^{-3}\right)$ and HF $\left(45.7 \mu \mathrm{g} \mathrm{m}^{-3}\right)$. The difference between the minimum and maximum of hourly $\mathrm{O}_{3}$ concentrations was the highest $\left(89.4 \mu \mathrm{g} \mathrm{m}^{-3}\right)$ in GZ.

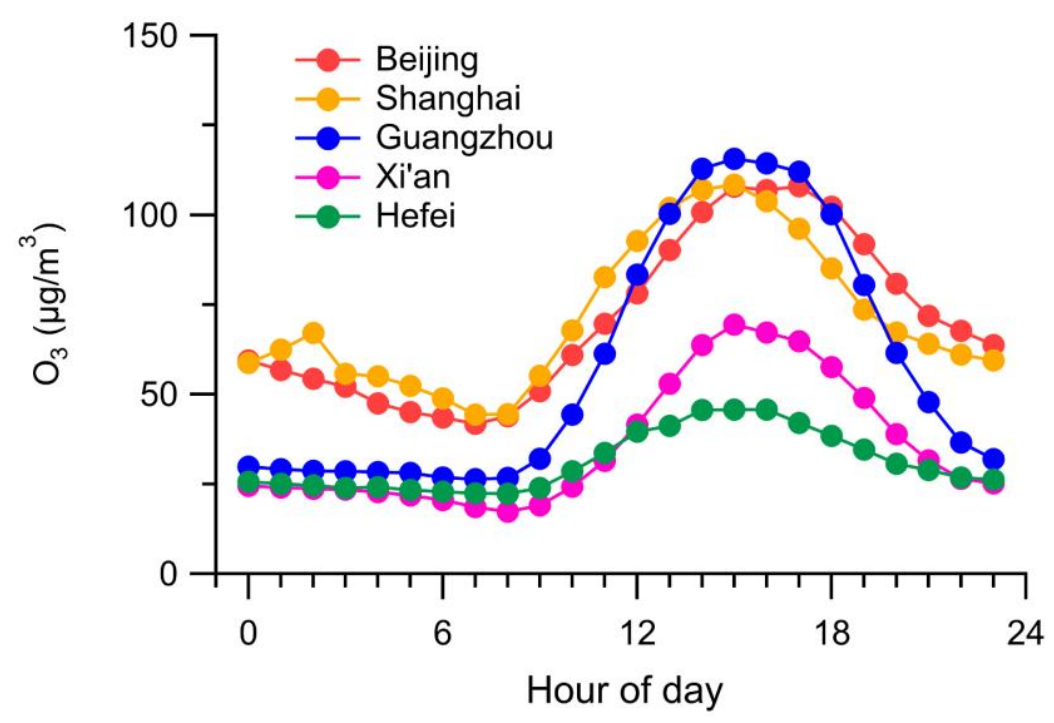

Figure 4. Diurnal variations of hourly $\mathrm{O}_{3}$ concentrations in the five cities. 


\subsection{Effects of Air Pollutants and Meteorological Parameters on $M D A 8 \mathrm{O}_{3}$ Levels}

Ozone forms photochemically in the presence of $\mathrm{NO}_{x}$ and VOCs. Thus, the emissions of precursors and meteorological conditions have strong impacts on $\mathrm{O}_{3}$ production. Moreover, aerosol can affect radiation through both absorption and scattering, which can influence $\mathrm{O}_{3}$ formation. We show the seasonal variations of the other five criteria air pollutants $\left(\mathrm{NO}_{2}, \mathrm{CO}, \mathrm{SO}_{2}, \mathrm{PM}_{2.5}\right.$, and $\left.\mathrm{PM}_{10}\right)$ in Figure 5, and the seasonal variations of temperature, relative humidity, and wind speed in Figure 6. The concentrations of the other five criteria air pollutants exhibited opposite trends to $\mathrm{MDA} 8 \mathrm{O}_{3}$ in $\mathrm{BJ}$, $\mathrm{SH}$, and $\mathrm{GZ}$, i.e., the highest values in winter with broad ranges and the lowest values in summer with narrow ranges. In $\mathrm{XA}$, the five air pollutants showed similar trends, except $\mathrm{NO}_{2}$, which was the lowest in autumn. However, the seasonal patterns of the five air pollutants in HF were different from the other four cities. $\mathrm{NO}_{2}, \mathrm{SO}_{2}, \mathrm{PM}_{2.5}$, and $\mathrm{PM}_{10}$ had the lowest values in summer, while $\mathrm{NO}_{2}$ and $\mathrm{PM}_{10}$ peaked in autumn, and $\mathrm{SO}_{2}$ and $\mathrm{PM}_{2.5}$ peaked in winter. $\mathrm{CO}$ exhibited a distinct trend following the order of autumn $>$ winter $>$ summer $>$ spring. The different seasonal patterns of the five air pollutants could relate to the different $\mathrm{O}_{3}$ trend in HF.

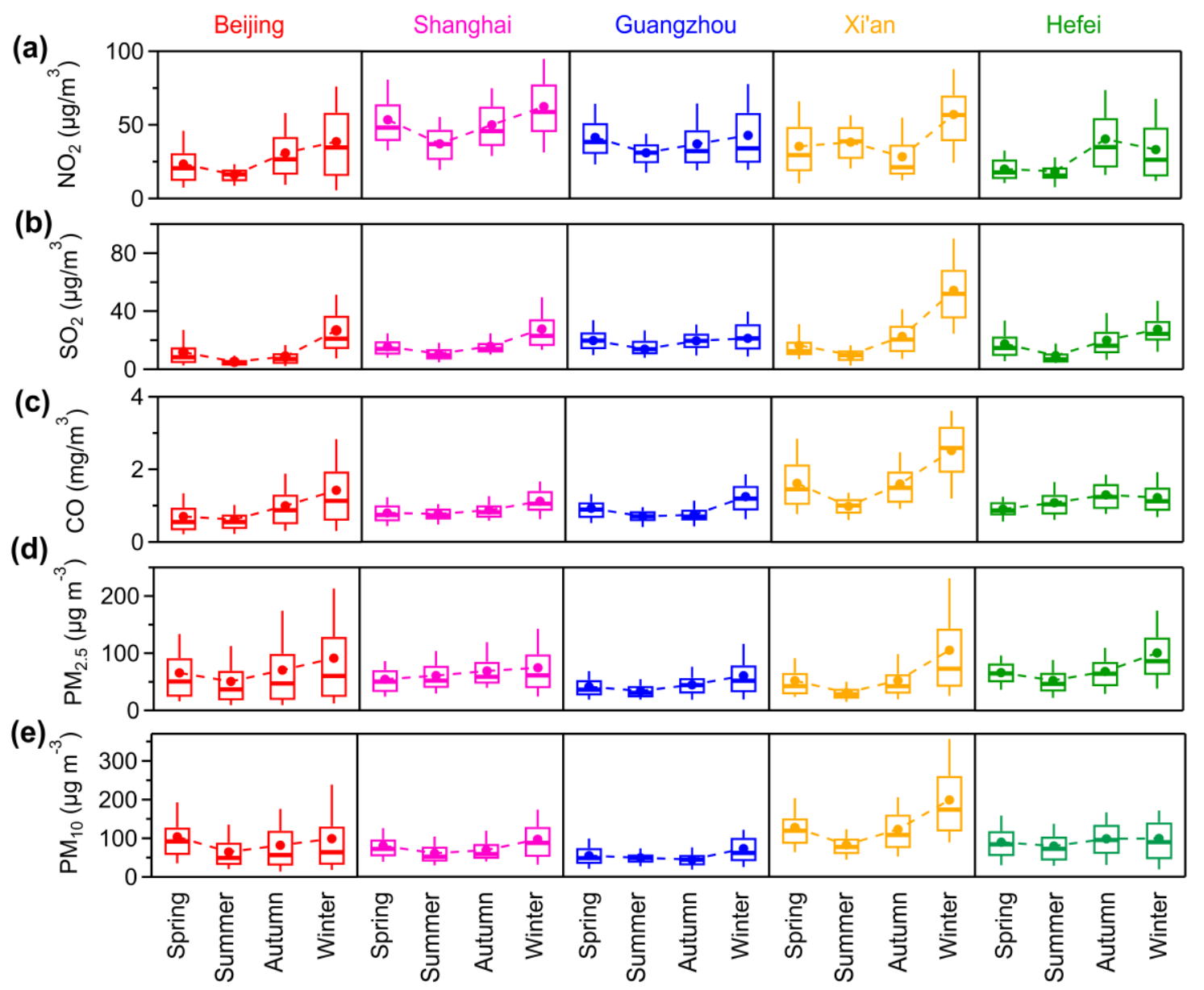

Figure 5. Seasonal variations of $\mathrm{NO}_{2}(\mathbf{a}), \mathrm{SO}_{2}(\mathbf{b}), \mathrm{CO}(\mathbf{c}), \mathrm{PM}_{2.5}(\mathbf{d})$, and $\mathrm{PM}_{10}(\mathbf{e})$ concentrations in the five cities. The boxes represent the 25 th percentile (lower edge), median (solid line), mean (dot with das line), and 75th percentile (upper edge). The whiskers above and below the box indicate the 90th percentile and 10 th percentile. 

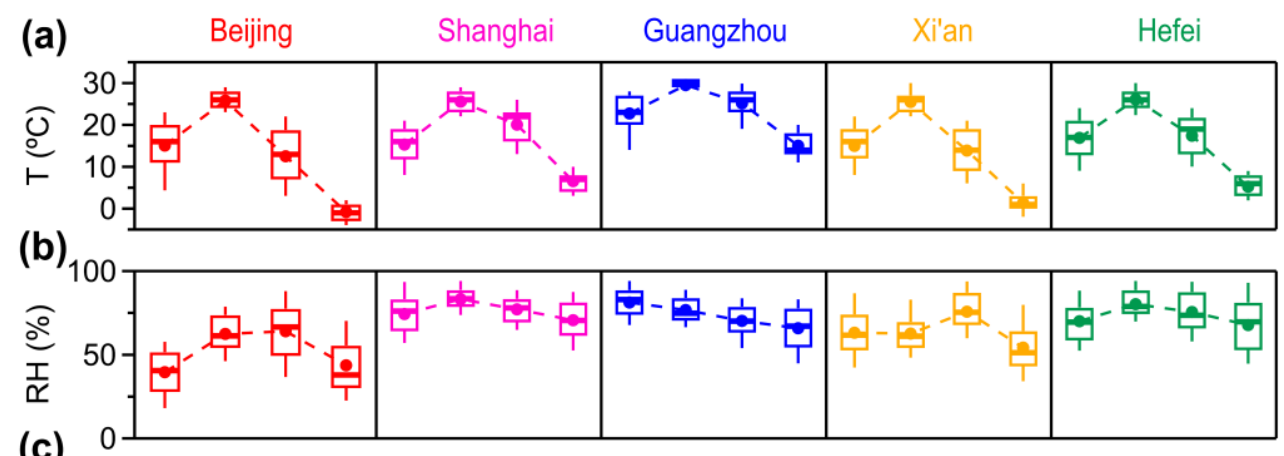

(c)

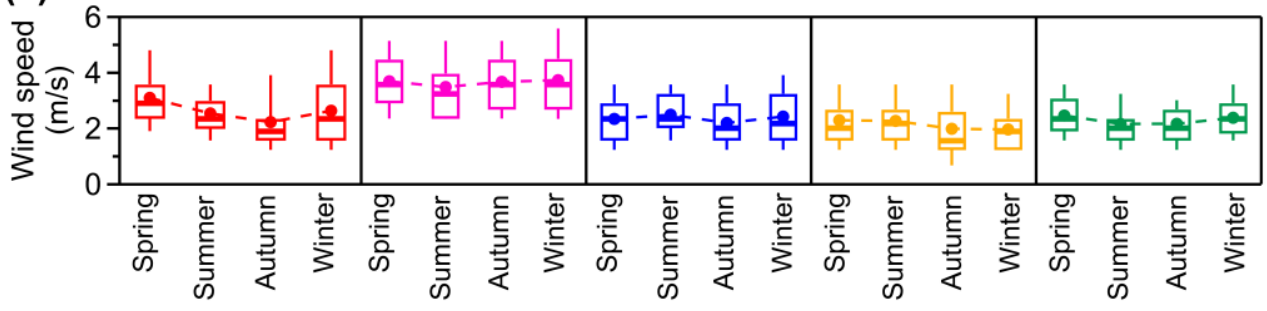

Figure 6. Seasonal variations of temperature (a), relative humidity (b) and wind speed (c) in the five cities. The boxes represent the 25 th percentile (lower edge), median (solid line), mean (dot with das line), and 75th percentile (upper edge). The whiskers above and below the box indicate the 90th percentile and 10th percentile.

The averages of temperature in all the five cities were the highest in summer and lowest in winter with narrow ranges, while the values in spring and autumn were close with broad ranges. In BJ, summer and autumn $\mathrm{RH}$ values were higher $(\sim 60 \%)$ than spring and winter. Howeer, RH values of all the seasons in $\mathrm{SH}, \mathrm{GZ}$, and HF were higher than that in $\mathrm{BJ}$. RH values in $\mathrm{SH}$ and $\mathrm{HF}$ had similar seasonal trends with highest values in summer and lowest in winter. In GZ, RH had a decreasing trend from spring to winter. $\mathrm{RH}$ values in XA were in the order of autumn $>$ spring $>$ summer $>$ winter, with the lowest value of $54 \%$ in winter. The averages of wind speed in $\mathrm{SH}, \mathrm{GZ}, \mathrm{XA}$, and HF were quite stable in all seasons, with the highest values in SH ( 3.5 to $3.7 \mathrm{~m} / \mathrm{s})$ and similar values $(2.0-2.5 \mathrm{~m} / \mathrm{s})$ in other three cities. In BJ, wind speed values showed a distinct seasonal variation, with higher values in spring and winter and lower values in summer and autumn.

The relationship between $\mathrm{MDA} 8 \mathrm{O}_{3}$ and other air pollutants as well as meteorological parameters was quantified using Spearman-Rank correlation coefficient (IBM SPSS Statistics, version 19.0), as shown in Table 2. The correlations also showed seasonal and spatial variations. In BJ, MDA8 $\mathrm{O}_{3}$ had a good positive correlation with the five criteria air pollutants in summer, and became weakly correlated with them in spring; meanwhile, it was negatively correlated with the five criteria air pollutants in autumn and winter. This correlation trend for $\mathrm{NO}_{2}$ and $\mathrm{CO}$ could be due to a decreasing photochemical production from summer to winter, as suggested by Wang, et al. [38]. Note that examining the variability of $\mathrm{O}_{3}$ in parallel with $\mathrm{Ox}$ and $\mathrm{NO}_{x}$ can obtain a better understanding of the atmospheric sources and influencing factors of $\mathrm{O}_{3}$ formation $[39,40]$. Thus, future studies are suggested to include monitoring $\mathrm{NO}$ concentrations. $\mathrm{SO}_{2}$ does not directly involve $\mathrm{O}_{3}$ formation, but it can act as an indicator of industrial emissions contributing to $\mathrm{O}_{3}$ formation [41]. The positive correlations between $\mathrm{O}_{3}$ and $\mathrm{PM}_{2.5}$, as well as $\mathrm{PM}_{10}$, suggested the simultaneous formation of secondary $\mathrm{O}_{3}$ and $\mathrm{PM}$ by photochemical reactions in summer [42]. The negative correlations in winter could be due to high concentrations of PM formed by other pathways [43], leading to a reduction in solar radiation needed for $\mathrm{O}_{3}$ formation. In $\mathrm{SH}$, fairly positive correlations in summer and negative correlations in winter were also found between $\mathrm{O}_{3}$ and the other five air pollutants. In $\mathrm{GZ}, \mathrm{O}_{3}$ was positively correlated with $\mathrm{SO}_{2}, \mathrm{PM}_{2.5}$ and $\mathrm{PM}_{10}$ in all seasons. The good correlation with $\mathrm{SO}_{2}$ suggested that precursors emitted from industry significantly contributed to $\mathrm{O}_{3}$ formation. In XA, the correlations 
between $\mathrm{O}_{3}$ and other air pollutants were weak in all seasons. In $\mathrm{HF}, \mathrm{O}_{3}$ was highly correlated with $\mathrm{NO}_{2}(r=0.97, p<0.01)$, but not correlated with CO in autumn.

Table 2. Spearman-Rank correlation coefficient Values of $\mathrm{MDA} 8 \mathrm{O}_{3}$ with the other five criteria air pollutants and meteorological parameters.

\begin{tabular}{|c|c|c|c|c|c|c|c|c|c|}
\hline & & $\mathrm{NO}_{2}$ & $\mathrm{CO}$ & $\mathrm{SO}_{2}$ & $\mathbf{P M}_{2.5}$ & $\mathrm{PM}_{10}$ & Temp & RH & WS \\
\hline \multirow{4}{*}{$\begin{array}{c}\text { Beijing, } \\
\text { MDA8 O }_{3}\end{array}$} & spring & 0.12 & 0.06 & 0.08 & $0.32 * *$ & $0.29 * *$ & $0.73^{* *}$ & $0.38 * *$ & 0.07 \\
\hline & summer & $0.52 * *$ & $0.41^{* *}$ & $0.36^{* *}$ & $0.61^{* *}$ & $0.65^{* *}$ & $0.35 * *$ & 0.05 & 0.11 \\
\hline & autumn & $-0.58^{* *}$ & $-0.44^{* *}$ & $-0.31^{* *}$ & $-0.22 * *$ & $-0.19 * *$ & $0.71 * *$ & $-0.21^{* *}$ & 0.15 \\
\hline & winter & $-0.77^{* *}$ & $-0.68^{* *}$ & $-0.50^{* *}$ & $-0.61^{* *}$ & $-0.47^{* *}$ & -0.12 & $-0.40^{* *}$ & 0.14 \\
\hline \multirow{4}{*}{$\begin{array}{l}\text { Shanghai, } \\
\text { MDA8 O }_{3}\end{array}$} & spring & 0.11 & $-0.18 *$ & 0.05 & $0.25 * *$ & $0.36^{* *}$ & $0.51 * *$ & $-0.21^{* *}$ & -0.01 \\
\hline & summer & $0.21^{* *}$ & 0.19 * & $0.44^{* *}$ & 0.58 ** & $0.48^{* *}$ & 0.15 & -0.17 * & -0.09 \\
\hline & autumn & $-0.21^{* *}$ & 0.03 & 0.05 & 0.10 & 0.13 & $0.61 * *$ & -0.15 & -0.07 \\
\hline & winter & $-0.44^{* *}$ & $-0.23^{* *}$ & $-0.29 * *$ & $-0.17 *$ & -0.18 * & 0.10 & 0.12 & $0.21^{* *}$ \\
\hline \multirow{4}{*}{$\begin{array}{l}\text { Guangzhou, } \\
\text { MDA8 } \mathrm{O}_{3}\end{array}$} & spring & 0.10 & 0.01 & $0.49 * *$ & $0.32 * *$ & $0.45^{* *}$ & $0.34 * *$ & $-0.37^{* *}$ & 0.06 \\
\hline & summer & -0.06 & 0.07 & $0.37^{* *}$ & $0.48^{* *}$ & $0.63^{* *}$ & $0.52^{* *}$ & $-0.52^{* *}$ & $-0.39^{* *}$ \\
\hline & autumn & $0.26^{* *}$ & -0.13 & $0.40^{* *}$ & $0.68^{* *}$ & 0.61 ** & 0.00 & -0.14 & $0.24^{* *}$ \\
\hline & winter & 0.06 & 0.00 & $0.45^{* *}$ & $0.48^{* *}$ & $0.43^{* *}$ & 0.05 & $-0.30 * *$ & $-0.37^{* *}$ \\
\hline \multirow{4}{*}{$\begin{array}{c}\text { Xi'an, MDA8 } \\
\mathrm{O}_{3}\end{array}$} & spring & $-0.27^{* *}$ & $-0.26^{* *}$ & -0.12 & -0.06 & $-0.27^{* *}$ & $0.56^{* *}$ & $-0.25^{* *}$ & 0.13 \\
\hline & summer & 0.12 & $-0.15^{*}$ & $0.16^{*}$ & $0.20^{* *}$ & 0.15 * & $0.54^{* *}$ & $-0.30^{* *}$ & $0.32 * *$ \\
\hline & autumn & $-0.23 * *$ & $-0.36^{* *}$ & $-0.26^{* *}$ & -0.07 & -0.17 * & $0.60^{* *}$ & -0.14 & $0.27^{* *}$ \\
\hline & winter & $-0.17^{*}$ & 0.05 & $-0.23^{* *}$ & -0.01 & 0.06 & $0.16^{*}$ & -0.10 & 0.15 \\
\hline \multirow{4}{*}{$\begin{array}{c}\text { Hefei, MDA8 } \\
\mathrm{O}_{3}\end{array}$} & spring & 0.12 & 0.14 & $0.73^{* *}$ & $-0.26^{* *}$ & -0.01 & $-0.19 * *$ & -0.02 & -0.00 \\
\hline & summer & $-0.25 * *$ & 0.03 & 0.06 & 0.11 & $0.34^{* *}$ & $-0.18 *$ & -0.07 & 0.01 \\
\hline & autumn & $0.97^{* *}$ & 0.09 & $0.42 * *$ & 0.04 & -0.15 & -0.13 & -0.09 & 001 \\
\hline & winter & 0.07 & 0.02 & -0.19 * & -0.12 & 0.09 & 0.02 & $0.23 * *$ & 0.06 \\
\hline
\end{tabular}

Meteorological parameters also play important roles in $\mathrm{O}_{3}$ formation. For example, temperature has direct influences on ozone production through speeding up the rates of chemical reactions and increasing the emissions of VOCs, such as isoprene from vegetation [44]. In this study, positive correlations were also observed between $\mathrm{O}_{3}$ and temperature, especially for summer. However, the correlations were very weak and negative in HF in all seasons. Further studies are warranted to understand the relationship between $\mathrm{O}_{3}$ and temperature in HF. Relative humidity showed negative correlations with $\mathrm{O}_{3}$ in most of the seasons in all cities. However, water vapor is needed in the production of $\mathrm{OH}$, which oxidizes hydrocarbons to produce peroxyl radicals, an intermediate product that reacts with $\mathrm{NO}_{x}$ to produce $\mathrm{O}_{3}$ [30]. The negative correlations suggested that water vapor would not be a limiting factor in $\mathrm{O}_{3}$ formation as $\mathrm{RH}$ was usually higher $40 \%$. Conversely, $\mathrm{RH}$ had a positive correlation with $\mathrm{O}_{3}$ in spring in $\mathrm{BJ}$ when $\mathrm{RH}$ varied from $17 \%$ to $60 \%$. Wind speed can have multiple influences on $\mathrm{O}_{3}$ levels [45] and thus various correlations were observed between $\mathrm{O}_{3}$ and wind speed in different seasons in the five cities. With the increase of wind speed, the stability of the boundary layer starts to decrease with more $\mathrm{O}_{3}$ being transported to the surface layer from the upper layer [46]. However, increased wind speed can also enhance the dispersion of $\mathrm{O}_{3}$, which will offset the contributions of $\mathrm{O}_{3}$ from the upper layer [47]. However, increased wind speed can remove $\mathrm{PM}$ and thus increase solar radiation, which enhances $\mathrm{O}_{3}$ formation [14]. In this section, we mainly discussed the effects of other air pollutants and meteorological parameters on the formation of surface $\mathrm{O}_{3}$. It should be noted that tropospheric $\mathrm{O}_{3}$ can also influence the concentrations of surface $\mathrm{O}_{3}$ and therefore should be taken into account in comprehensively understanding the factors influencing the levels of surface $\mathrm{O}_{3}$. In particular, the tropospheric $\mathrm{O}_{3}$ usually reaches its maxima during summer and may subsequently influence the concentrations of surface $\mathrm{O}_{3}$ depending on the prevailing synoptic meteorological conditions [48]. 


\subsection{Transport Pathways of $\mathrm{O}_{3}$ or Its Precursors during $\mathrm{O}_{3}$ Episodes}

Figure 7 shows the results of $48 \mathrm{~h}$ air mass back-trajectory calculation with CWT (left panel) and PSCF (right panel) analyses during $\mathrm{O}_{3}$ episodes in the five cities. Here, the $\mathrm{O}_{3}$ episodes were defined as $8 \mathrm{~h} \mathrm{O}_{3}$ concentrations exceeding $160 \mu \mathrm{g} \mathrm{m}^{-3}$ or hourly $\mathrm{O}_{3}$ concentrations exceeding $200 \mu \mathrm{g} \mathrm{m}^{-3}$ $\left(160 \mu \mathrm{g} \mathrm{m}^{-3}\right.$ for XA and HF). Note that most of the $\mathrm{O}_{3}$ episodes occurred in summer. The detailed clustering results of the air mass back-trajectory for ozone pollution days in the five cities are shown in Table 3. The air mass transport was divided into short and long-distance transport according to transport distance. The lifetime of $\mathrm{O}_{3}$ in the air is short owing to its active chemical properties, so the effect of air mass transport on $\mathrm{O}_{3}$ mainly reflected in the transport of its precursors. As the proportion results shown in Figure 7 and Table 3, the impact of short-distance transport was greater than long-distance transport.

Table 3. Distribution characteristics of air mass backward trajectories during $\mathrm{O}_{3}$ episodes.

\begin{tabular}{|c|c|c|c|c|}
\hline \multirow{2}{*}{ City } & \multicolumn{2}{|c|}{ Short-Distance Transport } & \multicolumn{2}{|c|}{ Long-Distance Transport } \\
\hline & Air Mass Source & Proportion & Transport Pathway & Proportion \\
\hline \multirow{3}{*}{ Beijing } & Shijiazhuang & $38.5 \%$ & $\begin{array}{c}\text { Mongolia-Inner } \\
\text { Mongolia-Shanxi-Hebei }\end{array}$ & $7.7 \%$ \\
\hline & Inner Mongolia & $26.9 \%$ & \multirow{2}{*}{$\begin{array}{l}\text { Russia-Heilongjiang-Inner } \\
\text { Mongolia-Hebei }\end{array}$} & \multirow{2}{*}{$3.8 \%$} \\
\hline & Tianjin & $15.4 \%$ & & \\
\hline \multirow{4}{*}{ Shanghai } & Anhui & $27.0 \%$ & \multirow{2}{*}{ Guangdong-Jiangxi-Anhui } & \multirow{2}{*}{$24.3 \%$} \\
\hline & Yellow Sea & $16.2 \%$ & & \\
\hline & Jiangsu & $13.5 \%$ & \multirow{2}{*}{$\begin{array}{c}\text { Mongolia-Inner } \\
\text { Mongolia-Shaanxi-Shanxi- } \\
\text { Henan-Anhui }\end{array}$} & \multirow{2}{*}{$8.1 \%$} \\
\hline & Zhejiang & $10.8 \%$ & & \\
\hline \multirow[t]{3}{*}{ Guangzhou } & \multirow[t]{2}{*}{ South China Sea } & \multirow[t]{2}{*}{$27.3 \%$} & $\begin{array}{l}\text { South Jiangxi -North } \\
\text { Guangdong; South China } \\
\text { Sea-Hainan Island }\end{array}$ & $22.7 \%$ \\
\hline & & & Chongqing-Hubei-Hunan & $9.1 \%$ \\
\hline & Hainan & $13.6 \%$ & Dongsha Islands & $4.5 \%$ \\
\hline \multirow[t]{2}{*}{ Xi'an } & \multirow[t]{2}{*}{ Qinling Mountain } & \multirow[t]{2}{*}{$25.0 \%$} & $\begin{array}{l}\text { Mongolia-Inner } \\
\text { Mongolia-Ningxia; } \\
\text { Shandong-Henan }\end{array}$ & $16.7 \%$ \\
\hline & & & $\begin{array}{l}\text { Xinjiang-Qinghai-South } \\
\text { Gansu; East Tibet-North } \\
\text { Sichuang }\end{array}$ & $8.3 \%$ \\
\hline \multirow{3}{*}{ Hefei } & \multirow{2}{*}{ Huainan } & \multirow{2}{*}{$30.8 \%$} & Shandong Peninsula-Jiangsu & $15.4 \%$ \\
\hline & & & Hubei-Jiangxi-South Anhui & $11.5 \%$ \\
\hline & East Henan-Jiangsu & $19.2 \%$ & Guangdong-Hunan-Hubei & $3.8 \%$ \\
\hline
\end{tabular}


(a)

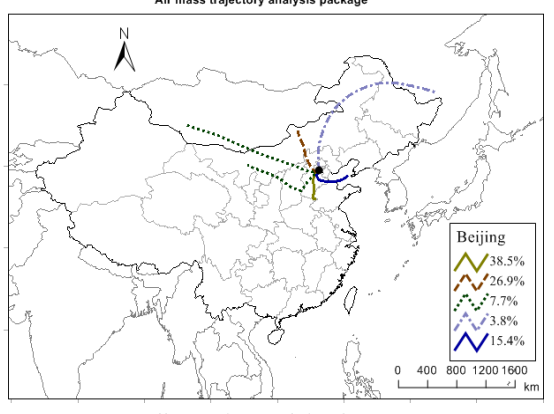

(b)

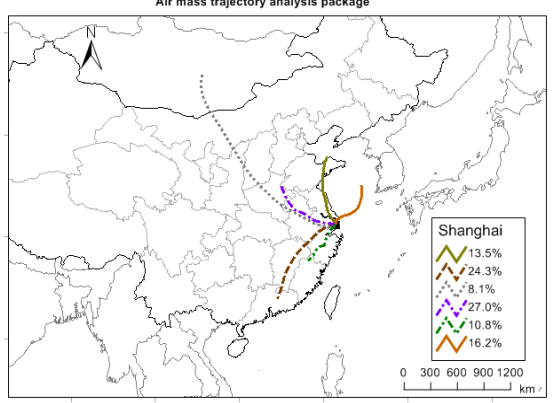

(c)

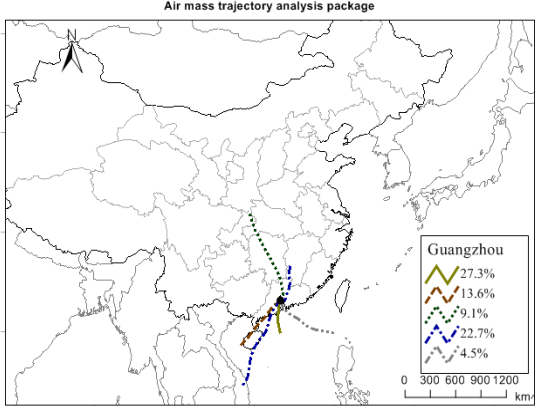

(d)

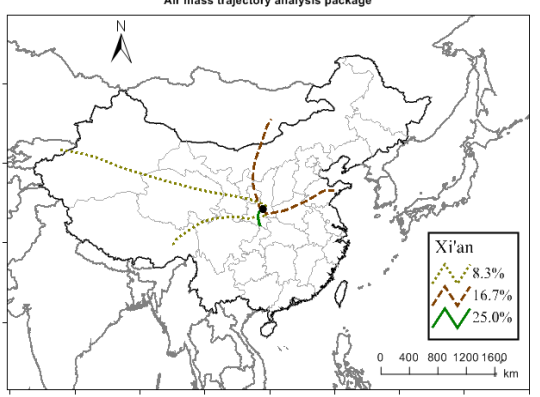

(e)

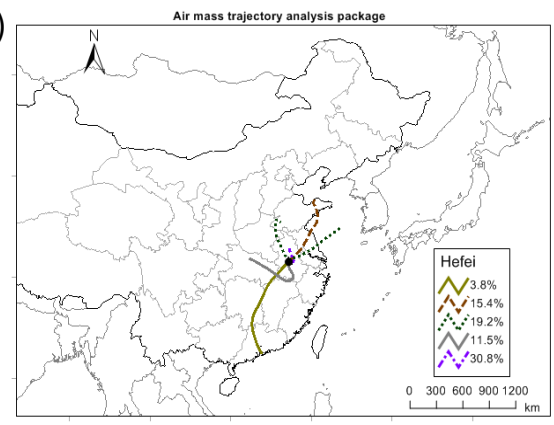

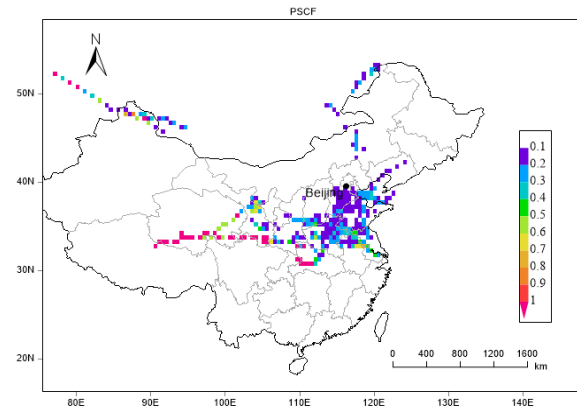
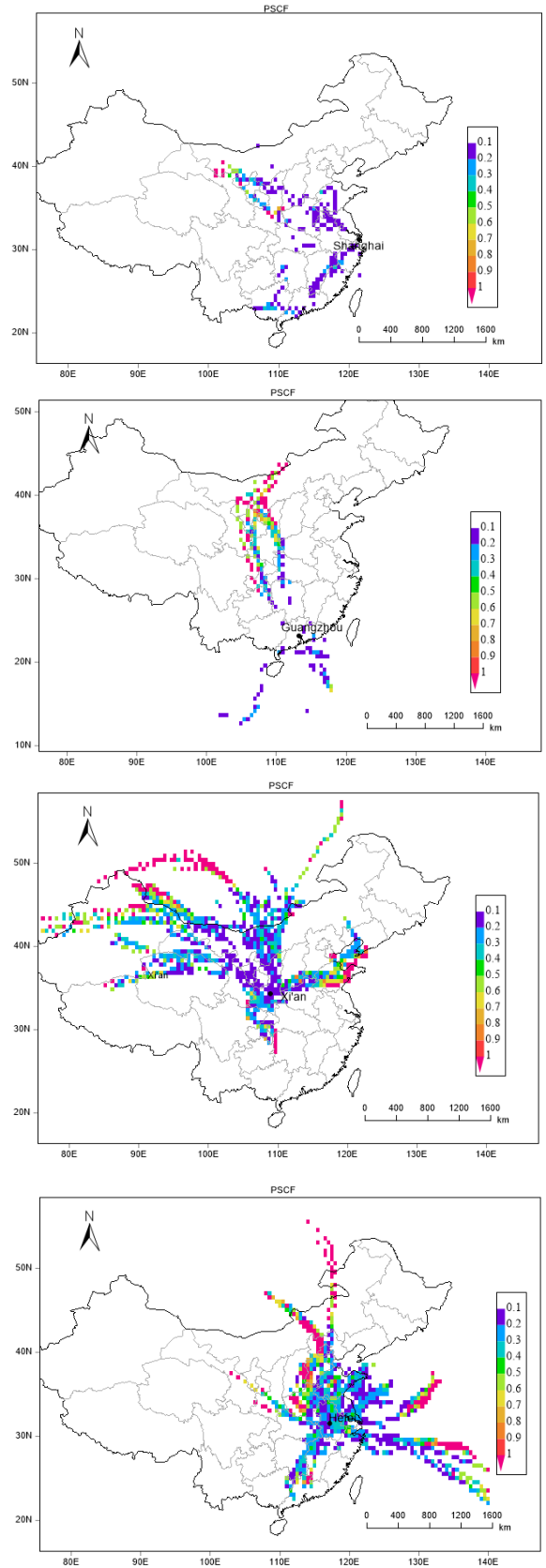

Figure 7. $48 \mathrm{~h}$ air mass back-trajectory during $\mathrm{O}_{3}$ episodes. The left column is the clustering analysis with an 8-h $\mathrm{O}_{3}$ concentrations exceeding $160 \mu \mathrm{g} \mathrm{m}^{-3}$; the right column is the PSCF with hourly $\mathrm{O}_{3}$ concentrations exceeding $200 \mu \mathrm{g} \mathrm{m}^{-3}$ in Beijing (a), Shanghai (b) and Guangzhou (c), and hourly $\mathrm{O}_{3}$ concentrations exceeding $160 \mathrm{~g} \mathrm{~m}^{-3}$ in $\mathrm{Xi}^{\prime}$ an (d) and Hefei (e). 
In BJ, the trajectory of polluted air mass from Shijiazhuang accounted for 38.5\%, followed by Inner Mongolia (26.9\%) and Tianjin (15.4\%). Shijiazhuang was one of the most polluted cities in China, which had high levels of $\mathrm{NO}_{x}$ and $\mathrm{CO}[49]$ and thus it could be the main source of $\mathrm{O}_{3}$ precursors transported to BJ. The main short-distance sources of air mass transport in $\mathrm{SH}$ was from the provinces around it, i.e., Anhui (27.0\%), Jiangsu (13.5\%), and Zhejiang (10.8\%). Another main source was from yellow sea $(16.2 \%)$, which could indicate a large source of VOC from the ocean during that period [50]. The main long-distance transport (24.3\%) to SH was from Guangdong passing through Jiangxi and Anhui. In GZ, most of the air mass came from South China Sea and Hainan Island, while the inland sources of air mass were from Hunan and Jiangxi provinces. In XA, the main air mass was from Southern region of XA (25\%), i.e., the Qinling Mountain areas, which is a lush growth of vegetation region in late spring, summer and early autumn. The air mass passing through Qinling Mountain areas in the monsoon season was expected to have higher biogenic VOC [30]. In HF, the highest proportion of $30 \%$ of the polluted air mass was from the Northern region of HF, such as Huainan city. Huainan is an important industry city known for its coal industry and thermal power plants. Thus, the high concentrations of $\mathrm{NO}_{2}$ and anthropogenic VOCs in that area [51] could be a major source of precursors transported to HF.

\section{Conclusions}

This study analyzed surface $\mathrm{O}_{3}$ concentrations in five provincial cities that locate in different regions of China during 2014-2015. Our results showed that the top three megacities (BJ, SH, and GZ) experienced more severe $\mathrm{O}_{3}$ pollution. Different seasonal and monthly patterns of $\mathrm{MDA}_{8} \mathrm{O}_{3}$ were observed among the five cities. Results from the weekend effect analysis showed that the differences between weekend and weekday $\mathrm{O}_{3}$ levels were insignificant in all the five cities. The diurnal pattern was consistent among the five cities with the highest values in the afternoon and lowest values in the early morning.

Substantially different correlations between $\mathrm{O}_{3}$ and other air pollutants, as well as meteorological parameters, were observed among the five cities. These results suggested that the contributions of affecting factors on $\mathrm{O}_{3}$ formation were different in different regions in China, which was consistent with previous studies showing there were $\mathrm{NO}_{\mathrm{x}}$-limited, VOC-limited or mixed-limited regimes of $\mathrm{O}_{3}$ formation in China (Reference [12] and therein). Air mass cluster analyses during episodic days revealed that a greater impact for high $\mathrm{O}_{3}$ pollution in the five cities was from short-distance transport and thus region-oriented air pollution control measures are suggested. The results of this study demonstrate the complexity of $\mathrm{O}_{3}$ control in Chinese urban area due to the great divergence of air pollution among different regions. Further studies are warranted for a comprehensive understanding of $\mathrm{O}_{3}$ production and control in Chinese cities. For instance, besides the field measurements at surface sites, more vertical measurements of air pollutants and meteorological parameters are needed in future studies [12]. Additionally, the citywide average data can be classified into a few categories such as urban traffic, urban background, and rural background, to better understand the seasonal, spatial trends as well as weekend effects.

Author Contributions: Z.S., H.X., J.C. and R.Z. conceived and designed the experiments; X.W., Y.Z., Q.Z. and G.L. collected the data; X.W., Z.T., Y.L. and G.L. analyzed the data; X.W., Z.S. and R.Z. wrote the paper with input from all the authors. All authors have read and agreed to the published version of the manuscript.

Funding: This research was supported by the Natural Science Foundation of Shaanxi Province, China (2016ZDJC-22) and a grant from SKLLQG, Chinese Academy of Sciences (SKLLQG1616).

Conflicts of Interest: The authors declare no conflict of interest. 


\section{References}

1. Vingarzan, R. A review of surface ozone background levels and trends. Atmos. Environ. 2004, 38, 3431-3442. [CrossRef]

2. Thompson, M.L.; Reynolds, J.; Cox, L.H.; Guttorp, P.; Sampson, P.D. A review of statistical methods for the meteorological adjustment of tropospheric ozone. Atmos. Environ. 2001, 35, 617-630. [CrossRef]

3. Monks, P.S. Gas-phase radical chemistry in the troposphere. Chem. Soc. Rev. 2005, 34, 376-395. [CrossRef]

4. Shen, Z.; Cao, J.; Zhang, L.; Zhao, Z.; Dong, J.; Wang, L.; Wang, Q.; Li, G.; Liu, S.; Zhang, Q. Characteristics of surface $\mathrm{O}_{3}$ over Qinghai Lake area in Northeast Tibetan Plateau, China. Sci. Total Environ. 2014, 500, $295-301$. [CrossRef]

5. Monks, P.S.; Archibald, A.; Colette, A.; Cooper, O.; Coyle, M.; Derwent, R.; Fowler, D.; Granier, C.; Law, K.S.; Mills, G. Tropospheric ozone and its precursors from the urban to the global scale from air quality to short-lived climate forcer. Atmos. Chem. Phys. 2015, 15, 8889-8973. [CrossRef]

6. WHO. Review of Evidence on Health Aspects of Air Pollution: REVIHAAP project: Final Technical Report; WHO Regional Office for Europe Copenhagen: København, Danmark, 2013.

7. Turner, M.C.; Jerrett, M.; Pope, C.A., III; Krewski, D.; Gapstur, S.M.; Diver, W.R.; Beckerman, B.S.; Marshall, J.D.; $\mathrm{Su}$, J.; Crouse, D.L. Long-term ozone exposure and mortality in a large prospective study. Am. J. Respir. Crit. Care Med. 2016, 193, 1134-1142. [CrossRef] [PubMed]

8. Jerrett, M.; Burnett, R.T.; Pope, C.A., III; Ito, K.; Thurston, G.; Krewski, D.; Shi, Y.; Calle, E.; Thun, M. Long-term ozone exposure and mortality. N. Engl. J. Med. 2009, 360, 1085-1095. [CrossRef] [PubMed]

9. Fowler, D.; Amann, M.; Anderson, F.; Ashmore, M.; Cox, P.; Depledge, M.; Derwent, D.; Grennfelt, P.; Hewitt, N.; Hov, O. Ground-level ozone in the 21st century: Future trends, impacts and policy implications. In Royal Society Science Policy Report; UEA Digital Repository: Norwich, UK, 2008; Volume 15.

10. Simon, H.; Reff, A.; Wells, B.; Xing, J.; Frank, N. Ozone trends across the United States over a period of decreasing NOx and VOC emissions. Environ. Sci. Technol. 2014, 49, 186-195. [CrossRef] [PubMed]

11. Cooper, O.R.; Parrish, D.; Ziemke, J.; Cupeiro, M.; Galbally, I.; Gilge, S.; Horowitz, L.; Jensen, N.; Lamarque, J.-F.; Naik, V. Global distribution and trends of tropospheric ozone: An observation-based review. Elem. Sci. Anthr. 2014, 2,000029. [CrossRef]

12. Wang, T.; Xue, L.; Brimblecombe, P.; Lam, Y.F.; Li, L.; Zhang, L. Ozone pollution in China: A review of concentrations, meteorological influences, chemical precursors, and effects. Sci. Total Environ. 2017, 575, 1582-1596. [CrossRef]

13. Wang, W.-N.; Cheng, T.-H.; Gu, X.-F.; Chen, H.; Guo, H.; Wang, Y.; Bao, F.-W.; Shi, S.-Y.; Xu, B.-R.; Zuo, X. Assessing spatial and temporal patterns of observed ground-level ozone in China. Sci. Rep. 2017, 7, 3651. [CrossRef] [PubMed]

14. Zhang, H.; Wang, Y.; Hu, J.; Ying, Q.; Hu, X.-M. Relationships between meteorological parameters and criteria air pollutants in three megacities in China. Environ. Res. 2015, 140, 242-254. [CrossRef] [PubMed]

15. Li, R.; Wang, Z.; Cui, L.; Fu, H.; Zhang, L.; Kong, L.; Chen, W.; Chen, J. Air pollution characteristics in China during 2015-2016: Spatiotemporal variations and key meteorological factors. Sci. Total Environ. 2019, 648, 902-915. [CrossRef] [PubMed]

16. Gong, X.; Hong, S.; Jaffe, D.A. Ozone in China: Spatial distribution and leading meteorological factors controlling $\mathrm{O} 3$ in 16 Chinese cities. Aerosol Air Qual. Res. 2018, 18, 2287-2300. [CrossRef]

17. Lu, X.; Hong, J.; Zhang, L.; Cooper, O.R.; Schultz, M.G.; Xu, X.; Wang, T.; Gao, M.; Zhao, Y.; Zhang, Y. Severe surface ozone pollution in China: A global perspective. Environ. Sci. Technol. Lett. 2018, 5, 487-494. [CrossRef]

18. An, Z.; Huang, R.-J.; Zhang, R.; Tie, X.; Li, G.; Cao, J.; Zhou, W.; Shi, Z.; Han, Y.; Gu, Z. Severe haze in Northern China: A synergy of anthropogenic emissions and atmospheric processes. Proc. Natl. Acad. Sci. USA 2019, 116, 8657-8666. [CrossRef]

19. Chinese State Council. Atmospheric Pollution Prevention and Control Action Plan; Council, C.S., Ed.; Chinese State Council: Beijing, China, 2013. Available online: http://www.gov.cn/zwgk/2013-09/12/content_2486773.htm (accessed on 9 October 2013). (In Chinese)

20. Tian, G.; Qiao, Z.; Xu, X. Characteristics of particulate matter $\left(\mathrm{PM}_{10}\right)$ and its relationship with meteorological factors during 2001-2012 in Beijing. Environ. Pollut. 2014, 192, 266-274. [CrossRef] 
21. Xue, L.; Wang, T.; Gao, J.; Ding, A.; Zhou, X.; Blake, D.; Wang, X.; Saunders, S.; Fan, S.; Zuo, H. Ground-level ozone in four Chinese cities: Precursors, regional transport and heterogeneous processes. Atmos. Chem. Phys. 2014, 14, 13175-13188. [CrossRef]

22. Li, L.; Qian, J.; Ou, C.-Q.; Zhou, Y.-X.; Guo, C.; Guo, Y. Spatial and temporal analysis of Air Pollution Index and its timescale-dependent relationship with meteorological factors in Guangzhou, China, 2001-2011. Environ. Pollut. 2014, 190, 75-81. [CrossRef]

23. Shen, Z.; Cao, J.; Arimoto, R.; Han, Z.; Zhang, R.; Han, Y.; Liu, S.; Okuda, T.; Nakao, S.; Tanaka, S. Ionic composition of TSP and $\mathrm{PM}_{2.5}$ during dust storms and air pollution episodes at $\mathrm{Xi}$ 'an, China. Atmos. Environ. 2009, 43, 2911-2918. [CrossRef]

24. Han, Y.; Du, P.; Cao, J.; Eric, S.P. Multivariate analysis of heavy metal contamination in urban dusts of Xi'an, Central China. Sci. Total Environ. 2006, 355, 176-186.

25. Hu, J.; Wang, Y.; Ying, Q.; Zhang, H. Spatial and temporal variability of $\mathrm{PM}_{2.5}$ and $\mathrm{PM}_{10}$ over the North China Plain and the Yangtze River Delta, China. Atmos. Environ. 2014, 95, 598-609. [CrossRef]

26. Wang, Y.; Zhang, X.; Draxler, R.R. TrajStat: GIS-based software that uses various trajectory statistical analysis methods to identify potential sources from long-term air pollution measurement data. Environ. Model. Softw. 2009, 24, 938-939. [CrossRef]

27. Wu, Y.; Zhang, S.; Hao, J.; Liu, H.; Wu, X.; Hu, J.; Walsh, M.P.; Wallington, T.J.; Zhang, K.M.; Stevanovic, S. On-road vehicle emissions and their control in China: A review and outlook. Sci. Total Environ. 2017, 574, 332-349. [CrossRef] [PubMed]

28. NBSC. China Statistical Yearbook 2015; National Bureau of Statistic of China (NBSC): Beijing, China, 2015. (In Chinese)

29. MEP, C. Ambient Air Quality Standards. GB 3095-2012; China Environmental Science Press: Beijing, China, 2012.

30. Wang, X.; Shen, Z.; Cao, J.; Zhang, L.; Liu, L.; Li, J.; Liu, S.; Sun, Y. Characteristics of surface ozone at an urban site of Xi'an in Northwest China. J. Environ. Monit. 2012, 14, 116-126. [CrossRef]

31. Shao, M.; Zhang, Y.; Zeng, L.; Tang, X.; Zhang, J.; Zhong, L.; Wang, B. Ground-level ozone in the Pearl River Delta and the roles of VOC and NOx in its production. J. Environ. Manag. 2009, 90, 512-518. [CrossRef]

32. Xie, M.; Zhu, K.; Wang, T.; Chen, P.; Han, Y.; Li, S.; Zhuang, B.; Shu, L. Temporal characterization and regional contribution to $\mathrm{O} 3$ and NOx at an urban and a suburban site in Nanjing, China. Sci. Total Environ. 2016, 551, 533-545. [CrossRef]

33. Wang, Y.; Hu, B.; Ji, D.; Liu, Z.; Tang, G.; Xin, J.; Zhang, H.; Song, T.; Wang, L.; Gao, W.; et al. Ozone weekend effects in the Beijing-Tianjin-Hebei metropolitan area, China. Atmos. Chem. Phys. 2014, 14, 2419-2429. [CrossRef]

34. Tang, W.; Zhao, C.; Geng, F.; Peng, L.; Zhou, G.; Gao, W.; Xu, J.; Tie, X. Study of ozone "weekend effect" in Shanghai. Sci. China Ser. D Earth Sci. 2008, 51, 1354-1360. [CrossRef]

35. Pont, V.; Fontan, J. Comparison between weekend and weekday ozone concentration in large cities in France. Atmos. Environ. 2001, 35, 1527-1535. [CrossRef]

36. Abeleira, A.J.; Farmer, D.K. Summer ozone in the northern Front Range metropolitan area: Weekend-weekday effects, temperature dependences, and the impact of drought. Atmos. Chem. Phys. 2017, 17, 6517-6529. [CrossRef]

37. Tong, L.; Zhang, H.; Yu, J.; He, M.; Xu, N.; Zhang, J.; Qian, F.; Feng, J.; Xiao, H. Characteristics of surface ozone and nitrogen oxides at urban, suburban and rural sites in Ningbo, China. Atmos. Res. 2017, 187, 57-68. [CrossRef]

38. Wang, T.; Cheung, V.T.; Anson, M.; Li, Y. Ozone and related gaseous pollutants in the boundary layer of eastern China: Overview of the recent measurements at a rural site. Geophys. Res. Lett. 2001, 28, 2373-2376. [CrossRef]

39. Kalabokas, P.D.; Viras, L.G.; Bartzis, J.G.; Repapis, C.C. Mediterranean rural ozone characteristics around the urban area of Athens. Atmos. Environ. 2000, 34, 5199-5208. [CrossRef]

40. Kley, D.; Geiss, H.; Mohnen, V.A. Tropospheric ozone at elevated sites and precursor emissions in the United States and Europe. Atmos. Environ. 1994, 28, 149-158. [CrossRef]

41. Zhao, S.; Yu, Y.; Yin, D.; Qin, D.; He, J.; Dong, L. Spatial patterns and temporal variations of six criteria air pollutants during 2015 to 2017 in the city clusters of Sichuan Basin, China. Sci. Total Environ. 2018, 624, 540-557. [CrossRef] 
42. Wang, Y.; Ying, Q.; Hu, J.; Zhang, H. Spatial and temporal variations of six criteria air pollutants in 31 provincial capital cities in China during 2013-2014. Environ. Int. 2014, 73, 413-422. [CrossRef]

43. Wang, G.; Zhang, R.; Gomez, M.E.; Yang, L.; Zamora, M.L.; Hu, M.; Lin, Y.; Peng, J.; Guo, S.; Meng, J. Persistent sulfate formation from London Fog to Chinese haze. Proc. Natl. Acad. Sci. USA 2016, 113, 13630-13635. [CrossRef]

44. Coates, J.; Mar, K.A.; Ojha, N.; Butler, T.M. The influence of temperature on ozone production under varying NO x conditions-A modelling study. Atmos. Chem. Phys. 2016, 16, 11601-11615. [CrossRef]

45. Tu, J.; Xia, Z.-G.; Wang, H.; Li, W. Temporal variations in surface ozone and its precursors and meteorological effects at an urban site in China. Atmos. Res. 2007, 85, 310-337. [CrossRef]

46. Lal, S.; Naja, M.; Subbaraya, B. Seasonal variations in surface ozone and its precursors over an urban site in India. Atmos. Environ. 2000, 34, 2713-2724. [CrossRef]

47. Roberts-Semple, D.; Song, F.; Gao, Y. Seasonal characteristics of ambient nitrogen oxides and ground-level ozone in metropolitan northeastern New Jersey. Atmos. Pollut. Res. 2012, 3, 247-257. [CrossRef]

48. Gaudel, A.; Cooper, O.; Ancellet, G.; Barret, B.; Boynard, A.; Burrows, J.; Clerbaux, C.; Coheur, P.-F.; Cuesta, J.; Cuevas Agulló, E. Tropospheric Ozone Assessment Report: Present-day Distribution and Trends of Tropospheric Ozone Relevant to Climate and Global Atmospheric Chemistry Model Evaluation; University of California Press: Berkeley, CA, USA, 2018.

49. Zhao, S.; Yu, Y.; Yin, D.; He, J.; Liu, N.; Qu, J.; Xiao, J. Annual and diurnal variations of gaseous and particulate pollutants in 31 provincial capital cities based on in situ air quality monitoring data from China National Environmental Monitoring Center. Environ. Int. 2016, 86, 92-106. [CrossRef] [PubMed]

50. Guenther, A.; Hewitt, C.N.; Erickson, D.; Fall, R.; Geron, C.; Graedel, T.; Harley, P.; Klinger, L.; Lerdau, M.; McKay, W. A global model of natural volatile organic compound emissions. J. Geophys. Res. Atmos. 1995, 100, 8873-8892. [CrossRef]

51. National Research Council. Energy Futures and Urban Air Pollution: Challenges for China and the United States; National Academies Press: Cambridge, MA, USA, 2008.

(C) 2020 by the authors. Licensee MDPI, Basel, Switzerland. This article is an open access article distributed under the terms and conditions of the Creative Commons Attribution (CC BY) license (http://creativecommons.org/licenses/by/4.0/). 